\title{
Monitoring serum gold values to improve chrysotherapy in rheumatoid arthritis
}

\author{
A. LORBER, C. J. ATKINS, C. C. CHANG, Y. B. LEE, J. STARRS, AND \\ R. A. BOVY \\ From the University of Southern California School of Medicine, Department of Medicine, Rheumatic \\ Disease and Immunology Section, Los Angeles, California, and the Veterans Administration Hospital, Long \\ Beach, California
}

Forestier (1929) first used gold salts to treat rheumatoid arthritis (RA), and controlled studies (e.g. Empire Rheumatism Council, 1960, 1961) later confirmed their effectiveness. An empirical schedule of treatment (conventional chrysotherapy) evolved, using $50 \mathrm{mg}$. monthly, but this might be further improved if dosage could be adjusted for each patient according to the serum level of gold. Atomic absorption spectrophotometric analysis now makes practicable the repeated estimation of gold in serum and urine, offering a considerable advantage over the methods used by previous authors (Goodwin, 1954; Smith, Peak, Kron, Hermann, Deltoro, and Goldman, 1958; Freyberg, Block, and Levey, 1941).

We report below the results of a comparison of the effectiveness of fixed-dose conventional chrysotherapy with a dosage varied according to the concentration of gold in the serum of the individual patient.

\section{Material and methods}

CRITERIA FOR ADMISSION TO THE TRIAL

Patients meeting the criteria of the American Rheumatism Association for a diagnosis of definite or classical active polyarticular rheumatoid arthritis were admitted and all anti-rheumatic medication other than salicylates was terminated or reduced to minimal maintenance levels. The clinical characteristics of the nineteen women and four men included in the study are detailed in Table I. With the exception of the first five patients listed in Table I who had previously received chrysotherapy, they were assigned on a random basis (Fisher and Yates, 1938) to the conventional or adjusted therapy regimen.

DESIGN OF GOLD THERAPY

The control group $C$ received $100-1,200 \mathrm{mg}$. sodium auro-thiomalate (Merck, Sharpe, and Dohme) by intramuscular injection of $50 \mathrm{mg}$./week for 20 to 24 weeks. Thereafter, $50 \mathrm{mg}$. were given monthly followed by three weekly placebo injections (Tables I and II). The adjusted therapy group A also received a series of 20 to 24 injections of $50 \mathrm{mg}$. gold thiomalate. The dosage was then adjusted (usually to $75 \mathrm{mg}$.) to maintain a blood concentration of $300 \mu \mathrm{g}$. per cent. as determined by measuring the gold in the previous week's blood specimen. To eliminate the possibility of a differential response to the frequency of injections, all patients received weekly injections of either placebo (physiological saline) or gold as indicated. The first five patients listed in Table I designated as Group A* had been receiving gold therapy on a conventional dosage regimen when admitted to the study and thus are not included in the clinical comparison. These patients are, however, included in the study as their gold serum levels have been maintained above $300-400 \mu \mathrm{g}$./per cent. by the adjusted regimen for more than 4 years and thus represent the longest test periods available.

TESTING PROCEDURES AND MEASUREMENTS

At each patient's weekly examination, a complete blood count (CBC), serum gold levels, and urine analysis were determined. Every 20 weeks, a complete physical examination was made, including the subjective and objective response to treatment (Lansbury, 1966). A physiotherapist who was unaware of the dosages given recorded the range of joint motion including 28 variables (Heck, Hendryson, and Rowe, 1965). The patients were hospitalized* for 7 days at the 10th, 20th, and 60th week (and every 30 weeks thereafter) from the start of therapy for collection and daily quantitation of gold content in serum, urine, and (in some subjects) stool specimen. Comprehensive laboratory studies were conducted every 20 weeks to detect toxic or adverse reactions affecting haemopoietic, hepatic, or renal function; these included creatinine clearance, 24-hr protein excretion, and renal tubular concentration function.

Serum, urine, and faecal gold determinations were performed by atomic absorption spectroscopy, using an internal standard (Lorber, Cohen, Chang, and Anderson, 1968).

* Clinical Research Center Ward of the University of Southern California School of Medicine, Los Angeles. California, supported by Research Grant No. FR-43 from General Clinical Research Centers, NIH, John E. Bethune, M.D., Director. 
Table I Clinical particulars of 23 patients in order of admission to the trial

\begin{tabular}{|c|c|c|c|c|c|c|c|c|c|c|c|c|}
\hline $\begin{array}{l}\text { Patient } \\
\text { no. }\end{array}$ & $\begin{array}{l}\text { Date } \\
\text { admitted }\end{array}$ & Group & $\begin{array}{l}\text { Age } \\
\text { (yrs.) }\end{array}$ & Sex & Race & $\begin{array}{l}\text { Duration } \\
\text { of disease } \\
\text { (yrs.) }\end{array}$ & $\begin{array}{l}R F \\
\text { titre }\end{array}$ & $\begin{array}{l}\text { Anti- } \\
\text { DNP }\end{array}$ & LE Prep & Nodules & Erosions & $\begin{array}{l}\text { Functional } \\
\text { index }\end{array}$ \\
\hline 1 & Mar. '67 & $A^{*}$ & 39 & $\mathrm{~F}$ & W & 3 & $\overline{-}$ & - & - & - & + & III \\
\hline 2 & Apr. '67 & $\mathrm{A}^{*}$ & 49 & $\mathrm{~F}$ & $\mathbf{N}$ & $3 \cdot 5$ & 1,280 & - & - & - & + & III \\
\hline 3 & May'67 & A* & 51 & $\mathrm{~F}$ & W & 10 & 320 & - & - & - & + & II \\
\hline 4 & Jun. '67 & A* & 61 & $\hat{\mathrm{F}}$ & $\mathrm{O}$ & 8 & 5,120 & - & - & - & + & III \\
\hline 5 & Apr. '68 & A* & 42 & $\mathrm{~F}$ & W & 1 & 2,560 & - & - & + & + & III \\
\hline 6 & Aug. ' 68 & A & 29 & $\mathrm{~F}$ & $\mathrm{~N}$ & 6 & 2,560 & - & - & - & + & III \\
\hline 7 & Aug. ' 68 & A & 68 & M & $\mathrm{N}$ & 3 & 320 & - & - & - & + & III \\
\hline 8 & Oct. '68 & C & 45 & $F$ & $\mathrm{~N}$ & 3 & 5,120 & + & - & - & + & IV \\
\hline 9 & Oct. '68 & $\mathrm{C}$ & 39 & $\mathrm{~F}$ & W & 4 & 640 & + & - & - & + & II \\
\hline 10 & Nov. '68 & A & 31 & $\mathrm{~F}$ & W & 11 & 2,560 & + & - & - & + & II \\
\hline 11 & Nov. '68 & A & 47 & $\mathrm{~F}$ & W & 2 & 1,280 & + & - & - & + & II \\
\hline 12 & Nov. '68 & C & 48 & $\mathrm{~F}$ & $\mathbf{N}$ & 20 & 2,560 & - & - & - & + & III \\
\hline 13 & Dec. '68 & $\mathrm{C}$ & 57 & M & $\mathbf{N}$ & $<1$ & 10,240 & - & - & - & + & II \\
\hline 14 & Jan. '69 & $\mathrm{C}$ & 46 & M & W & 3 & 5,120 & - & - & - & - & II \\
\hline 15 & Jan. '69 & $\mathrm{C}$ & 47 & $\mathrm{~F}$ & $\mathrm{~W}$ & 4 & 1,280 & - & - & + & + & III \\
\hline 16 & Feb. ' 69 & A & 38 & $\mathrm{~F}$ & $\mathrm{~N}$ & 3 & 2,560 & - & - & - & + & III \\
\hline 17 & Apr. '69 & $\mathrm{C}$ & 51 & $\mathrm{~F}$ & W & 18 & 5,120 & - & - & + & + & III \\
\hline 18 & Apr. ' 69 & $\mathrm{C}$ & 44 & $\mathrm{~F}$ & W & 1 & 640 & - & - & - & + & III \\
\hline 19 & Apr. '69 & A & 29 & $F$ & $\mathrm{~W}$ & 5 & 20,480 & + & $3+$ & + & + & III \\
\hline 20 & May '69 & A & 66 & $\mathrm{~F}$ & W & 2 & 5,120 & - & $2+$ & + & + & III \\
\hline 21 & Jun. '69 & A & 57 & $\mathrm{~F}$ & W & 19 & 5,120 & - & $1+$ & + & + & III \\
\hline 22 & Sept. '69 & A & 31 & $\mathrm{~F}$ & $\mathrm{~N}$ & 2 & 10,240 & - & - & - & + & II \\
\hline 23 & Oct. '69 & C & 40 & M & W & 3 & 1,280 & + & - & - & + & II \\
\hline
\end{tabular}

\section{Results}

During the first 20 -week period of therapy, approximately half of the subjects failed to achieve the specified level of $>300 \mu \mathrm{g}$. per cent. (Fig. 1). For
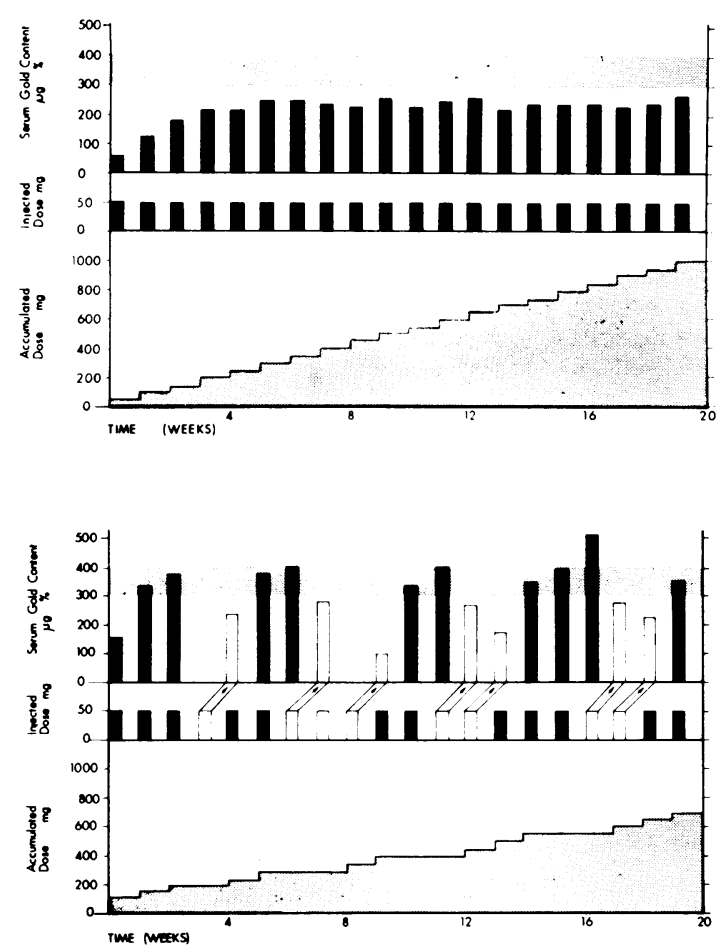

those patients scheduled to receive the adjuste therapy, the dosage was subsequently increased an $\mathbf{f}$ continued at weekly intervals as needed. Approx $\vec{F}$ mately 10 per cent. of the patients showed serum gold values exceeding the specified range during the initial 20-weeks and for them the dosage was omitted as necessary to maintain the desired range. Therapy for the control group was continued at an average dose of $56 \mathrm{mg}$. gold thiomalate/month compared with $183 \mathrm{mg}$./month for the adjusted group (Fig. 2; Table II). After the gold injection, a sharp increase in serum gold levels attains a maximum within 12 hours and falls gradually throughout the week. Thus, in the adjusted regimen, such peaks are attained three times more frequently than in patients treated under conventional monthly injection schedules. (Fig. 3, overleaf).

FIG. 1 Individual response by serum gold values to sequential 50-mg. injections of gold sodium thiomalate. Shaded band represents minimum serum gold level to be maintained.

(A) Specified range not attained in Patient 6. Additional weekly gold injections of 50-75 $\mathrm{mg}$. were required for the succeeding 40 weeks (see Table II).

(B) Patient 21 shows a much higher response during the initial period of chrysotherapy. For this reason, dosage was omitted at the fourth scheduled gold injection, and at subsequent times indicated by diagonal arrows. Excessively high serum gold levels would probably have resulted had the patient received weekly gold injections according to the conventional schedule. A striking clinical response was noted within 6 weeks of starting chrysotherapy in contrast to Patient 6 
Table II Comparison of weekly serum gold levels in patients $\dagger$ receiving different chrysotherapy regimens (21-60 week period)

\begin{tabular}{|c|c|c|c|c|c|c|c|c|c|c|c|c|}
\hline Therapy & Conven & tional & & & & & Adjuste & & & & & \\
\hline Patient no. & 8 & & 9 & & 12 & & 6 & & 16 & & 21 & \\
\hline $\begin{array}{l}\text { Week of } \\
\text { therapy }\end{array}$ & $\begin{array}{l}\text { Serum } \\
\text { level }\end{array}$ & $\begin{array}{l}\text { Dose } \\
\text { (mg.) }\end{array}$ & $\begin{array}{l}\text { Serum } \\
\text { level }\end{array}$ & $\begin{array}{l}\text { Dose } \\
\text { (mg.) }\end{array}$ & $\begin{array}{l}\text { Serum } \\
\text { level }\end{array}$ & $\begin{array}{l}\text { Dose } \\
\text { (mg.) }\end{array}$ & $\begin{array}{l}\text { Serum } \\
\text { level }\end{array}$ & $\begin{array}{l}\text { Dose } \\
\text { (mg.) }\end{array}$ & $\begin{array}{l}\text { Serum } \\
\text { level }\end{array}$ & $\begin{array}{l}\text { Dose } \\
\text { (mg.) }\end{array}$ & $\begin{array}{l}\text { Serum } \\
\text { level }\end{array}$ & $\begin{array}{l}\text { Dose } \\
\text { (mg.) }\end{array}$ \\
\hline 21 & 308 & * & 340 & * & 164 & * & 265 & 50 & 335 & 50 & 455 & $*$ \\
\hline 22 & 185 & $*$ & 198 & ${ }^{*}$ & 76 & $*$ & 216 & 50 & F.A. & $\overline{50}$ & 298 & 50 \\
\hline $\begin{array}{l}23 \\
24\end{array}$ & F.A. & $\overline{50}$ & 163 & * & 68 & * & 239 & 50 & 308 & 50 & 403 & 25 \\
\hline $\begin{array}{l}24 \\
25\end{array}$ & $\begin{array}{r}93 \\
190\end{array}$ & $\begin{array}{l}50 \\
*\end{array}$ & 140 & $\begin{array}{l}50 \\
*\end{array}$ & $\begin{array}{r}55 \\
152\end{array}$ & 50 & 228 & 50 & 330 & 50 & 363 & * \\
\hline 26 & 115 & $*$ & 183 & $*$ & 192 & $*$ & 220 & 50 & $\begin{array}{l}404 \\
528\end{array}$ & $*$ & 368 & $\begin{array}{l}50 \\
50\end{array}$ \\
\hline 27 & 78 & * & 100 & * & 155 & $*$ & 263 & 50 & 354 & $*$ & 465 & $*$ \\
\hline 28 & 75 & 50 & 135 & 50 & 93 & * & 258 & 50 & 252 & 50 & 273 & 25 \\
\hline 29 & 170 & $*$ & 229 & $*$ & 85 & 50 & 243 & 50 & F.A. & - & F.A. & $*$ \\
\hline 30 & 138 & * & 133 & * & 190 & $*$ & 253 & 50 & F.A. & - & 203 & 50 \\
\hline 31 & 113 & $*$ & 93 & $*$ & 110 & 50 & 273 & 50 & 183 & 50 & 340 & 25 \\
\hline 32 & 78 & 50 & 82 & 50 & 210 & 50 & 258 & 50 & 248 & 50 & 470 & 25 \\
\hline 33 & 185 & $*$ & 245 & * & 233 & * & 200 & 50 & 330 & 50 & F.A. & * \\
\hline 34 & 115 & $*$ & 133 & * & 158 & * & 220 & 50 & 385 & $*$ & F.A. & * \\
\hline 35 & 100 & $*$ & 115 & $*$ & 93 & $*$ & 185 & $62 \cdot 5$ & 305 & 50 & 155 & 50 \\
\hline 36 & 100 & 50 & 75 & 50 & 88 & 50 & 258 & $62 \cdot 5$ & 315 & 50 & 358 & 25 \\
\hline 37 & 135 & * & 237 & $*$ & 205 & $*$ & 213 & 62.5 & N.S. & 50 & 408 & 50 \\
\hline 38 & 110 & $*$ & 135 & * & 128 & $*$ & 280 & $62 \cdot 5$ & 350 & 50 & 418 & $*$ \\
\hline 39 & 63 & 50 & 114 & * & 103 & * & 285 & 75 & 399 & $*$ & F.A. & * \\
\hline 40 & F.A. & - & 91 & 50 & 73 & 50 & 345 & 75 & 345 & $*$ & Holiday & $y^{*}$ \\
\hline 41 & F.A. & - & 276 & $*$ & 175 & $*$ & 293 & 75 & 250 & 50 & 145 & 50 \\
\hline 42 & 72 & * & 168 & * & 100 & * & 338 & 50 & 318 & 50 & 333 & 50 \\
\hline 43 & 65 & 50 & 118 & * & 88 & $*$ & 398 & 50 & 343 & 50 & 413 & 25 \\
\hline 44 & 159 & $*$ & 110 & 50 & 78 & 50 & 268 & 50 & F.A. & - & 366 & $*$ \\
\hline 45 & 145 & * & 228 & * & 168 & * & 300 & 75 & 247 & 50 & 250 & 50 \\
\hline 46 & 89 & $*$ & 156 & * & 90 & * & 280 & 75 & 255 & 50 & 368 & 50 \\
\hline 47 & 57 & 50 & 145 & $*$ & 103 & $*$ & 218 & 75 & 358 & 50 & 448 & 50 \\
\hline 48 & 153 & $*$ & 123 & 50 & 80 & 50 & 260 & 75 & 400 & 50 & F.A. & $*$ \\
\hline 49 & 120 & * & 283 & $*$ & 208 & $*$ & 280 & 75 & 455 & $*$ & 315 & 25 \\
\hline 50 & 78 & $*$ & 213 & $*$ & 111 & * & 323 & 75 & 295 & * & 315 & 25 \\
\hline 51 & 66 & 50 & 160 & $*$ & 83 & $*$ & 388 & 50 & 220 & 50 & 324 & 25 \\
\hline 52 & 178 & $*$ & 145 & 50 & 100 & 50 & 321 & 50 & 280 & 50 & 326 & 25 \\
\hline 53 & 123 & * & 275 & $*$ & 160 & $*$ & 366 & 75 & 375 & 50 & 338 & 25 \\
\hline 64 & 98 & * & 195 & * & 130 & * & 364 & 50 & 365 & $*$ & F.A. & $*$ \\
\hline 55 & 100 & 50 & 145 & $*$ & 93 & $*$ & 330 & 50 & 285 & 50 & 249 & 50 \\
\hline 56 & 205 & $*$ & 110 & 50 & 68 & 50 & 335 & 50 & 370 & 50 & 378 & 50 \\
\hline 57 & 175 & * & 267 & 50 & 183 & $*$ & 300 & 50 & F.A. & - & 460 & 25 \\
\hline 58 & 108 & $*$ & F.A. & - & 111 & * & 348 & 50 & 213 & 50 & 461 & 25 \\
\hline 59 & 88 & 50 & 225 & * & 80 & * & 380 & 50 & F.A. & - & 390 & * \\
\hline 60 & 195 & & 143 & * & 68 & 50 & 375 & 50 & 223 & 50 & 293 & 50 \\
\hline
\end{tabular}

* Placebo or no gold.

F.A. = Failed appointment or clinic cancelled. $\quad$ N.S. $=$ No specimen

$\uparrow$ To conserve space, the tabulation for each group has been limited to three patients.

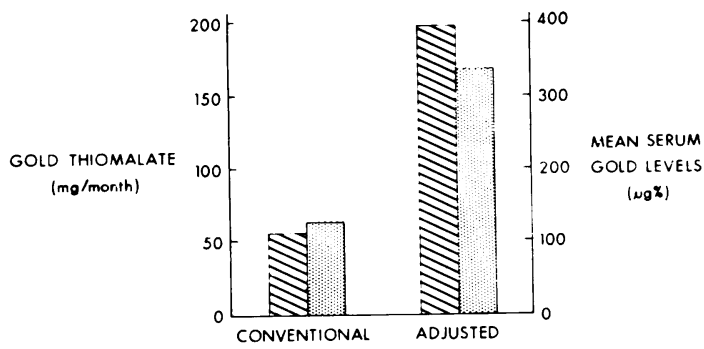

D Gold Dose (month)
FIG. 2 Relationship between dosage and resulting serum gold level beyond the 20th week of treatment for the two patient groups (conventional v. adjusted chrysotherapy)
Renal gold excretion approximated 35 per cent. of the weekly administered dose during the first 20-week period of therapy (Fig. 4, overleaf). Excretion then increased to approximately 45 per cent. of the dose for the adjusted therapy group and declined to 20 per cent. of the dose for the control group. With occasional exceptions, faecal gold excretion constitutes only approximately 5 per cent. of the administered dose. The faecal excretion for patients receiving adjusted therapy was greater than for the controls.

\section{ADVERSE REACTIONS (Table III, overleaf)}

In no instance was the percentage of adverse reactions greater in the test group than in the control group. 


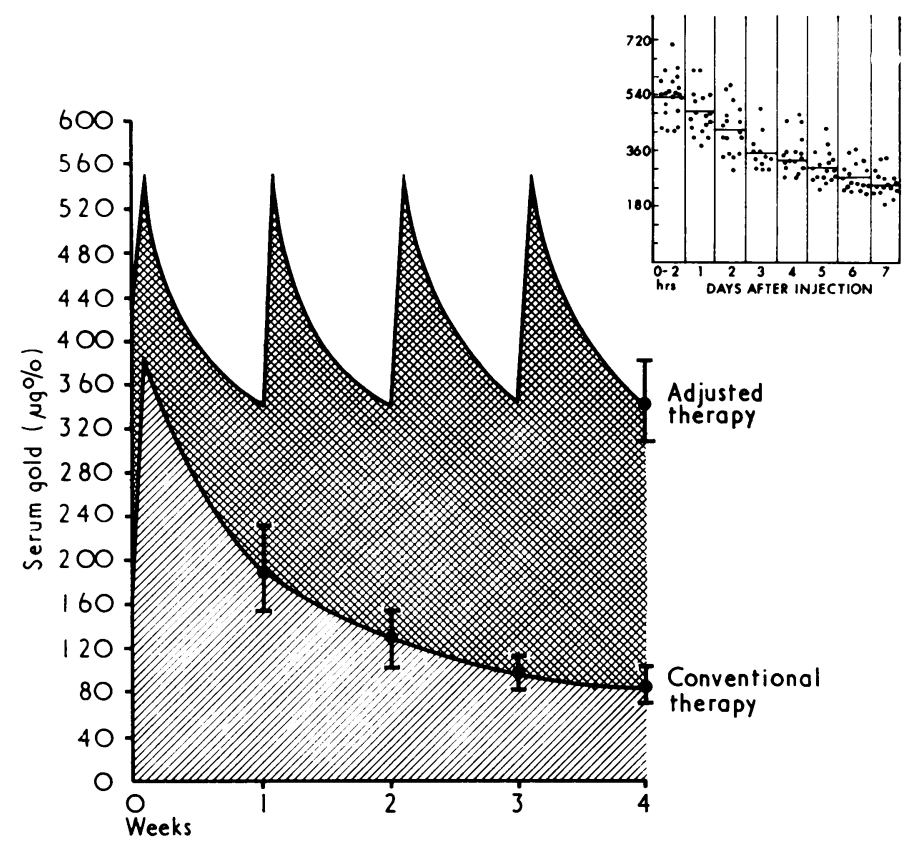

FIG. 3 Comparison of serum gold levels (beyond 20th week of treatment) in patients receiving conventional chrysotherapy (monthly gold injections) with those achieved by the adjusted regimen (weekly gold injections). [See inset Figure]. A sharp increase exceeding $500 \mu \mathrm{g}$. per cent. is seen within 2 hours after injection. Thereafter, there is a progressive fall during the ensuing week $(s)$. The differences in frequency and dosage of gold administration for the two groups are reflected in the ambient gold levels. The tissue distribution of gold and binding to immune reactants is is increased whenever the serum gold $\vec{\omega}$ concentration exceeds $300 \mu \mathrm{g}$. per cent

Table III Incidence of adverse reactions*

\begin{tabular}{|c|c|c|c|c|}
\hline \multirow{3}{*}{$\begin{array}{l}\text { Therapy } \\
\text { No. of patients }\end{array}$} & \multirow{2}{*}{\multicolumn{2}{|c|}{$\frac{\text { Conventional }}{10}$}} & \multirow{2}{*}{\multicolumn{2}{|c|}{$\frac{\text { Adjusted }}{16}$}} \\
\hline & & & & \\
\hline & No. & Per cent. & No. & Per cent. \\
\hline $\begin{array}{l}\text { Cutaneous } \\
\text { Dermatitis } \\
\text { Exfoliation }\end{array}$ & $\begin{array}{l}4 \\
0\end{array}$ & $\begin{array}{r}40 \\
0\end{array}$ & $\begin{array}{l}6 \\
0\end{array}$ & $\begin{array}{r}38 \\
0\end{array}$ \\
\hline $\begin{array}{l}\text { Renal } \\
\text { Haematuria } \\
\text { Proteinuria }\end{array}$ & $\begin{array}{l}5 \\
1 \dagger\end{array}$ & $\begin{array}{l}50 \\
10\end{array}$ & $\begin{array}{l}5 \\
1 \neq\end{array}$ & $\begin{array}{r}31 \\
6\end{array}$ \\
\hline $\begin{array}{c}\text { Haematopoietic } \\
\text { Leucopenia§ } \\
\text { Thrombo- } \\
\text { cytopenia } \\
\text { Eosinophilia }\end{array}$ & $\begin{array}{l}1 \\
0\end{array}$ & $\begin{array}{r}10 \\
0\end{array}$ & $\begin{array}{l}1 \\
0\end{array}$ & $\begin{array}{l}6 \\
0\end{array}$ \\
\hline
\end{tabular}

* All patients observed for a minimum period of 60 weeks. $+1+$ proteinuria, transient recurrent.

¥ Renal biopsy disclosed wire loop changes of renal SLE.

$\S$ No evidence of toxicity or bone marrow depression was noted on microscopic examination.

With regard to cutaneous reactions, the frequency of dermatitis attributed to gold was approximately 40 per cent. for both groups and was associated with eosinophilia in eight subjects; the latter preceded the rash in five subjects. In only two patients were the serum gold levels greater than $400 \mu \mathrm{g}$. per cent. at the onset of the rash. Apart from the eosinophilia, there was no irregularity in the differential white cell count. On one occasion, however, the latter constituted up to 33 per cent. of the differential count. With regard to an occasional report of microscopic haematuria ( 3 to 5 RBCs per high-power field), thę c/ highest serum gold level in association with the onse of the rash was $408 \mu \mathrm{g}$. per cent. Chrysotherapy was temporarily interrupted to conduct further studies, the results of which suggested that causes other than gold toxicity were responsible. No abnormality in hepatic or renal function was observed (Table IV).

COMPARISON OF EFFICACY

For each of eighteen patients 35 variables were recorded. Evaluation parameters included range of joint motion (28 variables), manual grip strength, erythrocyte sedimentation rate (Wintrobe), rheumatoid factor titre, Steinbrocker functional index (Steinbrocker, Traeger, and Batterman, 1949), and duration of morning stiffness. Patients included in this comparative study had not received chrysotherapy before admission to the study. Each group composed of nine patients manifested an approximately equal extent of improvement at the 20th week. $N$ Since divergence in dosage administration occurred primarily during the 20 th to 60 th weeks (Table II ; Fig. 2), $\mathbb{O}$ this interval was selected for comparison of the clinical $N$ response (Table V). The Kruskal Wallis one-way analysis of variance was applied for comparing the clinical response of the two therapy regimens. Statistical analysis indicated that patients who were receiving adjusted dosage therapy were significantly improved with regard to range of motion, grip strength, erythrocyte sedimentation rate, and decline in RF titre. Morning stiffness and the Steinbrocker functional index did not show a statistically significant difference between the two groups, though there was a tendency to a better rate of improvement with the adjusted therapy regimen. 


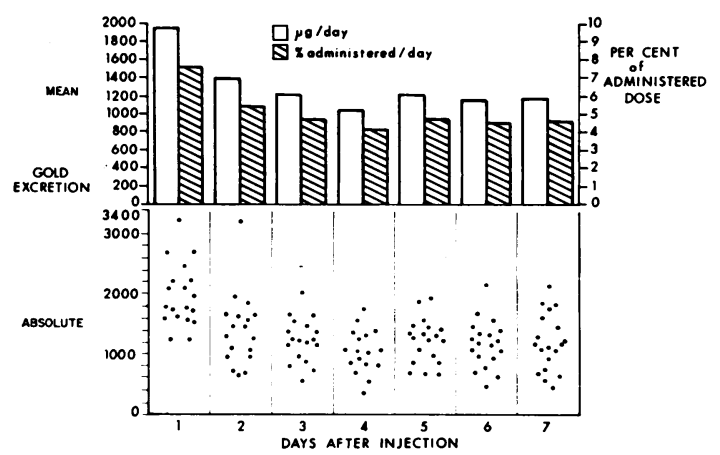

FIG. 4 Variation in individual urinary gold excretion indicated on scattergram. Each point represents the absolute daily urinary gold excretion per patient observed at the 20th week of therapy. The highest gold excretion is noted within 24 hours after injection. The open bars above show the mean daily gold excretion for this group. The striped bars show the daily percentage excretion of the weekly administered gold dosage. A consistent relationship between serum gold values and urinary gold excretion was not observed

\section{Discussion}

The data presented indicate that gold dosage can be safely adjusted on the basis of serum gold values to exceed $300 \mu \mathrm{g}$. per cent. to achieve positive clinical results. Basing the administered dosage on the amount of gold excreted in the urine as suggested by Smith and others, (1958) may be hazardous, as our results indicate that most of the administered gold was not recovered in urine or stool. In our experience, basing replacement therapy on levels of serum gold allows weekly administration of gold salts in higher dosage and for longer periods of time than has previously been reported. Serious adverse reactions were not encountered despite the sustained high levels. The frequent association of eosinophilia with dermatitis is suggestive of hypersensitivity rather than of gold toxicity. It is our impression that dermatitis was aggravated by wide fluctuations in serum gold content, thus supporting the concept of maintaining more constant levels.

From a theoretical standpoint, the higher sustained blood gold levels may exert a beneficial effect via one of several mechanisms. Transport of gold from blood to tissues, i.e, to the synovial fluid, should be enhanced. Higher tissue gold levels may facilitate the inhibition of acid hydrolases (Persellin and Ziff, 1966; Ennis, Granda, and Posner, 1968).

The distribution of gold to the various serum protein fractions also seems to be influenced by the serum gold concentrations. At levels achieved with conventional chrysotherapy, gold binds principally to serum albumin (McQueen and Dykes, 1969; Lawrence, 1961); at higher values, however, we have observed proportional binding of gold to immunoglobulins and complement (Lorber, Bovy, and Chang, 1972) (Fig. 3, opposite). Therefore, it may be possible, by regulating serum gold values, to increase the binding of gold to protein reactants involved in the formation of immune complexes which may then gain access to those cells engaged in phagocytosis of these complexes.

With regard to the efficacy of the programme, in view of the relatively small number of participants, no definitive conclusion should yet be drawn. It is nevertheless possible, on the basis of our observations, to make some generalizations regarding the relationships between clinical response and serum gold levels:

(1) Patients noted to have high serum gold levels early during therapy are more likely to manifest an early improvement, i.e. before 20 weeks.

(2) Conversely, patients who did not achieve the specified serum gold levels generally did not fare as well. This group is likely to include subjects considered to be non-responders to chrysotherapy.

Table IV Comparison of renal function studies between conventional $(C)$ and adjusted $(A)$ chrysotherapy groups

\begin{tabular}{|c|c|c|c|c|c|c|}
\hline Cumulative dose ${ }^{*}(\mathrm{~g})$. & $0-1$ & & $\overline{1-2}$ & & $2-3$ & $3-8$ \\
\hline Type of therapy & $C$ & $\boldsymbol{A}$ & $C$ & $\boldsymbol{A}$ & Adjusted $\ddagger$ & Adjusted $\ddagger$ \\
\hline $\begin{array}{l}\text { Creatinine clearance } \\
\left(\mathrm{ml} . / \mathrm{min} . / \mathrm{m} .{ }^{2}\right)\end{array}$ & 98 & 100 & 97 & 96 & 100 & 91 \\
\hline No. of patients & 10 & 11 & 6 & 9 & 9 & 16 \\
\hline No. of determinations & 25 & 29 & 7 & 11 & 9 & 31 \\
\hline $\begin{array}{l}\text { Pitressin concentration } \\
(\text { Osm/l.) }\end{array}$ & $0 \cdot 748$ & 0.711 & 0.674 & 0.717 & 0.737 & $0 \cdot 762$ \\
\hline No. of patients & 10 & 9 & 8 & 3 & 5 & 17 \\
\hline No. of determinations & 12 & 11 & 8 & 3 & 6 & 26 \\
\hline
\end{tabular}

* Total dosage of administered sodium aurothiomalate.

$\ddagger$ Patients on conventional therapy were routinely crossed over to adjusted therapy at 60 weeks (average cumulative dosage of $1,564 \mathrm{mg}$.).

Urinary protein excretion $>400 \mathrm{mg} / \mathrm{TV}$ was not observed (see text). 
Table $\mathrm{V}$ Results of adjusted and conventional gold therapy each in nine patients from 20 to 60 weeks

\begin{tabular}{|c|c|c|c|c|}
\hline \multirow[t]{2}{*}{ Criterion } & & \multicolumn{2}{|l|}{ Measurements } & \multirow{2}{*}{$\begin{array}{l}\text { Statistical } \\
\text { analysis }\end{array}$} \\
\hline & & Adjusted group & Conventional group & \\
\hline Range of joint motion & $\begin{array}{l}\text { No. of joints } \\
\text { No. improved at } 60 \mathrm{wks} \\
\text { No. worse }\end{array}$ & $\begin{array}{r}252 \\
165 \\
87\end{array}$ & $\begin{array}{l}252 \\
110 \\
142\end{array}$ & $\begin{array}{l}{ }^{*} \mathrm{P}<0.05 \\
{ }^{*} \mathrm{H}=4.304\end{array}$ \\
\hline Grip strength & $\begin{array}{l}\text { No. of tests } \\
\text { No. improved } \\
\text { No. worse }\end{array}$ & $\begin{array}{r}18 \\
10 \\
8\end{array}$ & $\begin{array}{r}18 \\
5 \\
13\end{array}$ & $* * \mathrm{P}<0.01$ \\
\hline $\begin{array}{l}\text { Erythrocyte sedimentation } \\
\text { rate (mm./1st hr) } \\
\text { (Wintrobe) }\end{array}$ & $\begin{array}{l}\text { No. of tests } \\
\text { Mean at } 20 \mathrm{wks} \\
\text { at } 60 \mathrm{wks}\end{array}$ & $\begin{array}{l}36 \\
33 \cdot 2 \\
27 \cdot 0\end{array}$ & $\begin{array}{l}36 \\
36 \cdot 0 \\
34 \cdot 2\end{array}$ & $\begin{array}{l}{ }^{*} \mathrm{P}<0.01 \\
{ }^{*} \mathrm{H}=8.24\end{array}$ \\
\hline Rheumatoid factor titre & $\begin{array}{l}\text { No. seropositive at } 20 \mathrm{wks} \\
\text { Decline in titre at } 60 \mathrm{wks} \\
\text { Total decline (tube dilution) }\end{array}$ & $\begin{array}{r}8 \\
7 \\
27\end{array}$ & $\begin{array}{r}8 \\
5 \\
12\end{array}$ & $\begin{array}{l}{ }^{*} \mathrm{P}<0.05 \\
{ }^{*} \mathrm{H}=2.93\end{array}$ \\
\hline $\begin{array}{l}\text { Steinbrocker functional } \\
\text { index } \dagger\end{array}$ & $\begin{array}{l}\text { No. improved at } 60 \mathrm{wks} \\
\text { No. worse } \\
\text { No. unchanged } \\
\text { Net change }\end{array}$ & $\begin{array}{r}3 \\
2 \\
4 \\
+3\end{array}$ & $\begin{array}{r}1 \\
6 \\
2 \\
-5\end{array}$ & **P $0 \cdot 10$ \\
\hline
\end{tabular}

* Kruskal Wallis one-way analysis of variance.

* Fisher's 'F' test.

† Steinbrocker, Traeger, and Batterman (1949).

(3) Such patients may, however, respond to therapy if gold administration is continued and the dosage adjusted to achieve the specified serum gold concentration.

(4) The beneficial response to chrysotherapy is more likely to be sustained if the serum gold concentration is maintained at or above $300 \mu \mathrm{g}$. per cent.

\section{Summary}

Serum gold levels, clinical response, and toxicity studies were compared in eighteen patients assigned on a random basis to receive chrysotherapy on either a fixed (conventional dosage) or individual (adjusted dosage) therapy schedule. Dosage for the latten group was adjusted on the basis of serum gold levelo to maintain values above $300 \mu \mathrm{g}$. per cent. Levels were monitored at weekly intervals by atomico absorption analyses. Significant differences in mean serum gold levels were recorded between the two therapy regimens: $136 v .322 \mu \mathrm{g}$. per cent.

Adjusted dosage therapy in some patients was continued for more than 4 years. The higher serum gold levels recorded for this group reflect the more sustained and larger dosages, but the incidence and severity of adverse reactions was not increased. Significant clinical benefits were recorded in subjects receiving adjusted dosage when compared with the group on the fixed dosage schedule.

\section{References}

Empire Rheumatism Council (1960) Ann. rheum. Dis., 19, 95 (Gold therapy in rheumatoid arthritis) (1961) Ibid., 20, 315 (Gold therapy in rheumatoid arthritis)

EnNis, R. S., Granda, J. L., AND Posner, A. S. (1968) Arthr. and Rheum., 11, 756 (Effect of gold salts and other drugs on the release and activity of lysosomal hydrolases)

Fisher, R. A., AND Yates, F. (1938) 'Statistical Tables for Biological Agricultural and Medical Research'. Oliver and Boyd, Edinburgh

Forestier, J. (1929) Bull. Soc. méd. Hôp. Paris, 53, 323 (L'Áurotherapie dans les rhumatismes chroniques)

FreyberG, R. H., BloCK, W. D., AND LeVEY, S. (1941) J. clin. Invest., 20, 401 (Metabolism, toxicity and manner of action of gold compounds used in treatment of arthritis; Human plasma and synovial fluid concentration and urinary excretion of gold during and following treatment, with gold sodium thiomalate, gold sodium thiosulfate, and colloidal gold sulfide)

Goodwin, J. F. (1964) J. Mich. St. med. Soc., 63, 437 (Some physiological implications of gold in serum and urine concentrations in chrysotherapy)

Heck, C. V., Hendryson, I. E., AND Rowe, C. R. (1965) 'Joint Motion-Method of Measuring and Recording'. American Academy of Orthopaedic Surgeons, Chicago

LANSBURY, J. (1966) 'Methods for Evaluating Rheumatoid Arthritis', in 'Arthritis and Allied Conditions', 7th ed., ed. J. L. Hollander, p. 269. Lea and Febiger, Philadelphia 
LaWrence, J. S. (1961) Ann. rheum. Dis., 20, 341 (Studies with radioactive gold)

LORBer, A., BOVY, R. A., AND ChANG, C. C. (1971) Arthr. and Rheum., 14, 172 (Binding of gold to rheumatoid factor: Correlation with serum gold levels)

, - _ - (1972) Nature (New Biology), 236, 250 (Relationship between serum gold content and distribution to serum immunoglobulins and complement)

COHEn, R. L., Chang, C. C., AND ANDerson, H. E. (1968) Arthr. and Rheum., 11, 170 (Gold determinations in biological fluids by atomic absorption spectrophotometer: Application to chrysotherapy in rheumatoid arthritis patients)

McQueEN, E. G., AND Dykes, P. W. (1969) Ann. rheum. Dis., 28, 437 (Transport of gold in the body)

Persellin, R. H., AND Ziff, M. (1966) Arthr. and Rheum., 9, 57 (The effect of gold salt on lysosomal enzymes of the peritoneal macrophage)

Smith, R. T., Peak, W. P., Kron, K. M., Hermann, I. F., Deltoro, R. A., and Goldman, M. (1958) J. Amer. med. Ass., 167, 1197 (Increasing the effectiveness of gold therapy in rheumatoid arthritis)

Steinbrocker, O., Traeger, C. H., and Batterman, R. C. (1949) J. Amer. med. Ass., 140, 659 (Therapeutic criteria in rheumatoid arthritis) 